\title{
Градостроительство в Республике Беларусь в XXI веке: ориентиры развития
}

\author{
Г.А.Потаев, БНТУ, Минск, Беларусь
}

Рассмотрены особенности развития градостроительства в Республике Беларусь в период с 1991 года по настоящее время. Это период формирования новой политики, определения приоритетов градостроительного развития. Выявлены имеющиеся проблемы, оценены возможности их преодоления. Рассмотрены вопросы формирования архитектурного облика белорусских городов, создания архитектурных символов современной эпохи.

Ключевые слова: градостроительство, урбанизация, градостроительная политика, приоритеты развития, городская среда, архитектурный облик города, индивидуальность облика города, туристские ресурсы города.

Urban Planning in the Republic of Belarus in the 21st Century: Development Points

G.A.Potaev, BNTU, Minsk, Belarus

The features of the development of urban planning in the Republic of Belarus in the period from 1991 to the present are considered. This is the period of forming a new policy, determining priorities for urban development. The existing problems are identified, the possibilities of overcoming them are assessed. The issues of the formation of the architectural appearance of Belarusian cities, the creation of architectural symbols of the modern era are considered.

Keywords: urban planning, urbanization, urban planning policy, development priorities, urban environment, architectural appearance of the city, individuality of the appearance of the city, tourist resources of the city

\section{Введение}

В 1991 году, когда Республика Беларусь, как и другие республики бывшего СССР, стала самостоятельным государством, все города имели разработанные и утвержденные генеральные планы развития. Имелась разработанная в 1987 году «Генеральная схема комплексной территориальной организации БССР», в которой было предложено реформирование административно-территориального устройства (вместо имевшихся шести областей, 218 районов и 1,5 тысяч сельских советов предлагалось создать 20 больших, 67 малых и 400 местных территориальных систем). Это позволяло значительно сократить число административных образований и органов территориального управления, оптимизировать размеры административных образований, улучшить условия транспортной доступности их центров (к сожалению, эти предложения остались нереализованными).

Кроме решения экономических проблем, необходимо было ликвидировать последствия катастрофы на Чернобыльской АЭС в 1986 году, в результате которой 23\% территории Беларуси, где проживало 2,2 млн человек, было загрязнено цезием-137 (св. 37 кБк/кв. м).

\section{Формирование новой градостроительной политики}

Экономический кризис 1990-х годов сопровождался спадом объемов жилищного, гражданского и производственного строительства. В этот период началась разработка новых законодательных и программных документов [Закон Республики Беларусь «0б основах архитектурной и градостроительной деятельности» (1993); «Градостроительная хартия Содружества Независимых Государств», подписаннная в Минске 4 июня 1999 года главами правительств государств-участников; проект «Градостроительной доктрины Республики Беларусь» (2003)], а также новых градостроительных нормативных документов [СНБ 1.03.01-96. Состав, порядок разработки и согласования градостроительных проектов (1996); СНБ 3.01.02-98. Состав, содержание, порядок создания и ведения государственного градостроительного кадастра (1999); СНБ 3.01.03-98. Государственный градостроительный кадастр. Порядок зонирования и установления регламентов градостроительного развития и использования территорий (1999); СНБ 3.03.02-97. Улицы и дороги городов, поселков и сельских населенных пунктов (1999) и др.].

В начале XXI века во многом изменилось представление о целях и методах развития городов и формирования городской среды. Обострились противоречия в понимании путей развития градостроительства:

- следовать традициям или развивать города инновационно?

- отдавать предпочтение местным, национальным или глобальным ценностям?

- формировать города с одностильной и упорядоченной или с эклектичной, но разнообразной застройкой?

- создавать моноцентричные или полицентричные города?

- отдавать предпочтение формированию камерных или крупномасштабных городских пространств?

- создавать «открытую и доброжелательную» городскую среду или «защищённую и безопасную»?

- создавать монокультурные или космополитичные города? 
При формировании, развитии, преобразовании таких сложных систем, как город, важно определить направленность процессов градостроительного развития. Сосуществуют часто противоположные идеи и их разнообразные интерпретации.

В Республике Беларусь, как и в большинстве европейских стран, приоритетами градостроительного развития определены:

- гуманизация городской среды - создание в городах условий, в которых людям удобно жить, работать, отдыхать, в которых люди активно участвуют в обсуждении имеющихся проблем и поиске путей развития городов;

- создание многофункциональной городской среды как нового формата жизни в городах со сближенным размещением мест проживания, работы, рекреации, получения услуг;

- создание творческой атмосферы в городах, развитие сети общественных пространств, где люди могут общаться, обмениваться идеями, создавать сообщества единомышленников, производить инновации, что улучшит инвестиционный климат и активизирует процессы экономического развития;

- сохранение и ревитализация историко-культурного наследия с целью его более рационального использования для современных потребностей людей;

- осознание значимости туризма как важной отрасли городской экономики;

- сохранение и(или) воссоздание природы в городах - гармоничное включение в городскую среду зелёных насаждений и водных устройств, приносящих людям радость общения с природой;

- создание «умных» городов, насыщенных новейшими технологиями с использованием телекоммуникационных систем, возобновляемых источников энергии (геотермальных, солнца, ветра, воды), экономии ресурсов и их рационального потребления;

- создание красивых городов с сомасштабными человеку пространствами, выразительной архитектурой, с произведениями искусства, включёнными в городскую среду [1;2].

Однако на практике эти постулаты далеко не всегда выполняются.

\section{Развитие городов в соответствии со Стратегией территориальной организации страны}

Главным территориально-планировочным документом страны является «Государственная схема комплексной территориальной организации Республики Беларусь» (РУП «БЕЛНИИПградостроительства», 2016), в соответствии с которой формируется урбанизированный каркас территории страны, включающий урбанизированные оси (транспортно-коммуникационные коридоры межнационального и национального значения с автомобильными и железнодорожными магистралями, линиями телекоммуникаций и электропередач, газо-, и нефтепроводов) и урбанизированные центры (узлы) - большие и средние города, расположенные вдоль и на пересечении основных транспортно-коммуникационных коридоров. Система урбанизированных центров и осей создаёт инфраструктурное поле, оказывающее влияние на все процессы экономического и социокультурного развития.

Экологическим противовесом зонам урбанизации служат природные территории - леса, реки, озера, водохранилища, выполняющие средорегулирующую функцию. На их основе формируется природно-экологический каркас территории страны, включающий природные центры (узлы) - особо охраняемые природные территории (национальные природные парки, заповедники, заказники), а также крупные лесные, лесо-озёрные, лесо-речные, болотные природные комплексы. Оси природно-экологического каркаса - линейные природные структуры, формируемые, как правило, вдоль рек и включающие водоохранные леса и другие природные территории. Они являются коридорами миграции диких животных, растений.

Сбалансированный состав и крупнодисперсное чередование в пространстве элементов урбанизированного и природно-экологического каркасов при соблюдении установленных режимов хозяйственной деятельности, поддержанных правовыми актами, способствуют предотвращению деградации среды обитания, поддержанию требуемого экологического равновесия. При этом важно достижение оптимального соотношения природных, сельскохозяйственных и высоко урбанизированных территорий как в масштабе страны, так и отдельных регионов.

В Республике Беларусь 77,5\% населения живёт в городах и посёлках городского типа. В стране 115 городов, в том числе: столица страны Минск; пять центров областей; десять городов областного подчинения; 99 городов районного подчинения, из них 92 районных центра; 90 посёлков городского типа, из них 12 районных центров; 23,2 тыс. сельских поселений, из них агрогородков - 1481 .

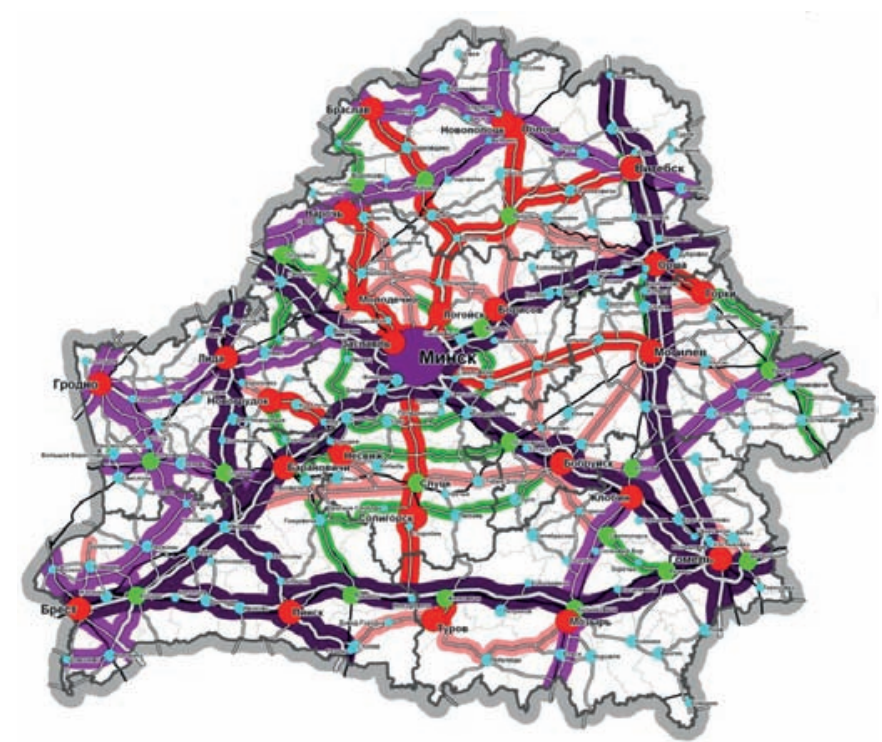

Рис. 1. Схема урбанизированного каркаса территории Республики Беларусь 
В Республике Беларусь, как и в других странах, наблюдается концентрация населения в крупных городах. Рост крупных городов обусловлен объективными преимуществами, которые создаются при концентрации экономических, финансовых, интеллектуальных ресурсов в этих городах. Они привлекают людей разнообразием предоставляемых услуг, возможностями получения качественного образования,

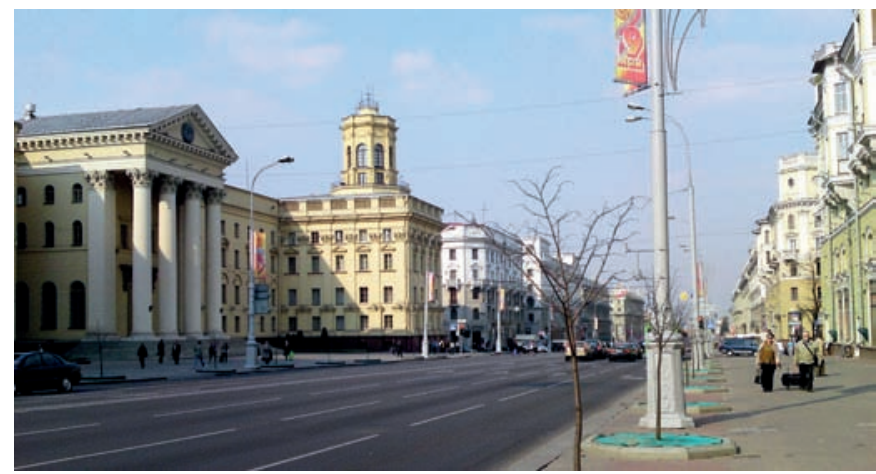

Рuс. 2. Ансамбль проспекта Сталина (ныне проспекта Независимости). Минск. Архитектор М. Парусников и др. ${ }^{*}$

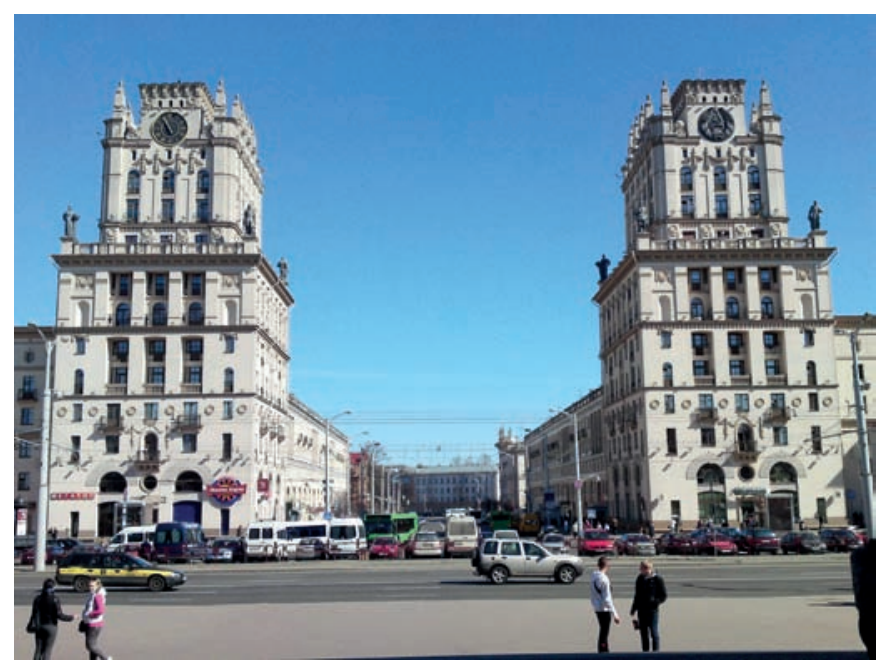

Рис. 3. «Ворота в город». Привокзальная площадь. Минск. Архитектор Б. Рубаненко и др.

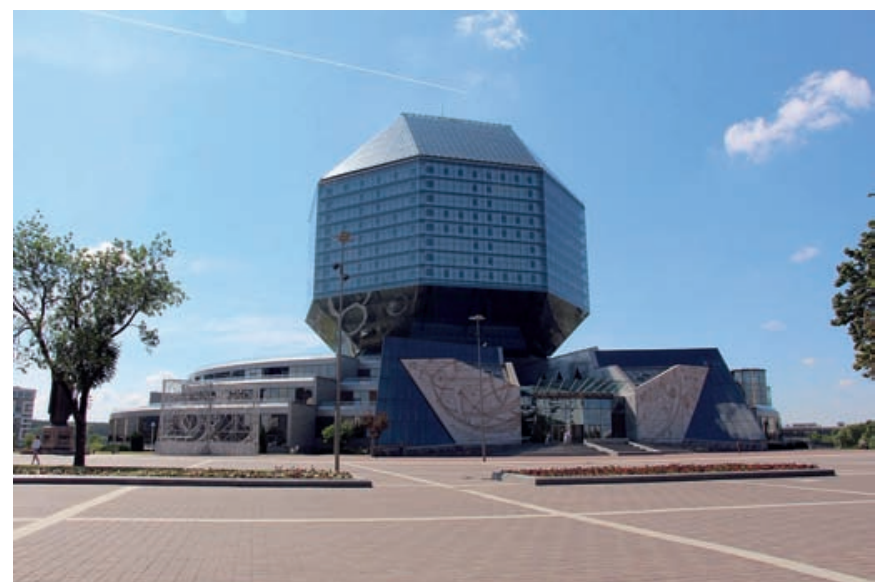

Рис. 4. Национальная библиотека Беларуси. Минск. Архитекторы В. Крамаренко и М. Виноградов трудоустройства, реализации амбициозных личных планов.

За период с 1991 по 2021 год уровень урбанизации в Республике Беларусь увеличился с 66,3\% до 77,5\%. Ожидается, что уровень урбанизации будут увеличиваться и в 2030 году превысит $80 \%$ [3].

В малых городских и сельских поселениях невозможно обеспечить все потребности современного человека в объектах образования, медицинского, культурного и других видов общественного обслуживания. Поэтому формируются системы расселения, объединяющие близко расположенные группы поселений, имеющие устойчивые связи с поселениемцентром, в котором сосредотачиваются объекты, обслуживающие все поселения системы расселения.

Совершенствование систем расселения связано, в первую очередь, с улучшением всех видов общественного обслуживания населения на районном, региональном и национальном уровнях, а также с повышением связности поселений, то есть сокращением затрат времени на доступность поселений-центров.

\section{Минск - «архитектурная витрина» страны}

Столица Республики Беларусь активно развивается. Минск - город, построенный во второй половине XX века (при этом город существует почти 1000 лет). До Великой Отечественной войны Минск был относительно небольшим городом с преобладанием деревянной одноэтажной застройки. Большая часть застройки сгорела и была разрушена во время войны. Период 1940-1950-х годов, после победы над фашистской Германией, был временем больших надежд. Восстанавливались разрушенные города, строилось коммунистическое общество. Архитектура и градостроительство должны были соответствовать идеалам коммунизма.

После войны Минск начали восстанавливать как идеальный коммунистический город с соответствующим архитектурным оформлением. В конце 1947 года был проведён конкурс на проект застройки центральной части главной улицы города - проспекта Сталина (ныне проспекта Независимости). Для реализации был принят проект М. Парусникова, разработанный под влиянием исторической архитектурной классики (рис. 2). Архитектурным символом Минск этого периода стали «Ворота в город» - два 11-этажных жилых башенных здания, размещённые на Привокзальной площади напротив железнодорожного вокзала (архитекторы Б. Рубаненко, Л. Голубовский, А. Корабельников, 1947 г., рис. 3) [4].

Среди архитектурных сооружений, построенных в последние десятилетия, которые могли бы олицетворять современный Минск, можно отметить: здание Национальной библиотеки Беларуси (архитекторы В. Крамаренко и М. Виноградов, 2006, рис. 4), Белорусский государственный музей Великой Отечественной войны (архитектор В. Крамаренко, 2014, рис. 5), возможно, некоторые другие. Однако

Все иллюстрации, использованные в статье, кроме особо оговоренных, взяты из открытых источников сети Интернет. 
оценки архитектурно-художественных достоинств этих зданий неоднозначны. Далеко не все соглашаются, что это символы современного, устремлённого в будущее Минска.

Особенностью Минска является искусственно созданная водно-парковая система. Город расположен на водоразделе бассейнов Балтийского и Черного морей, где имеются лишь малые реки и ручьи. Для обводнения города в 1970-1976 годы была построена Вилейско-Минская водная система протяжённостью 62 км с пятью насосными станциями, которые обеспечивают подъём воды на 75 м, что позволило перебрасывать около 380 млн куб. м воды в год из реки Вилии (бассейн Балтийского моря) в реку Свислочь (бассейн Черного моря) и увеличить проточность реки Свислочь в четыре-пять раз (до 17 кубических метров в секунду летом и 13 кубических метров в секунду зимой).

Вдоль реки Свислочь, которая пересекает город с северо-запада на юго-восток, создана водно-парковая система протяжённостью 25 км, включающая гирлянду водохранилищ, образуемых семью плотинами. Общая площадь водного зеркала составляет более 430 гектаров, вокруг которых размещены парки (рис. 6).

Слепянская и Лошицкая водно-парковые системы образуют два полукольца, расположенные в восточной и западной частях города и проходящие по жилым районам (рис. 7).

Для улучшения санации территории города, в дополнение к водно-парковым системам, предусмотрено формирование экологических коридоров в направлении господствующих ветров, что должно обеспечить приток обогащённого кислородом воздуха из пригородных лесов в центральные застроенные районы и их проветривание.

Система озеленённых пространств города формируется взаимосвязанно с пригородными озеленёнными территориями. Вокруг Минска создан лесопарковый пояс, в составе которого на расстоянии 15-30 км от города расположены зоны загородного отдыха, включающие большие площади лесов, места отдыха у водоёмов, рекреационные объекты [5].

Новых архитектурных ансамблей в Минске, к сожалению, немного. Можно выделить построенные вдоль проспекта Победителей ансамбли: жилой комплекс рядом с гостиницей Планета (рис. 8), комплексы офисных и спортивных объектов напротив унылой жилой застройки района «Лебяжий». Выразительное архитектурное решение имеют ансамбли вдоль проспекта Дзержинского: комплекс гостиницы «Ренессанс», жилой комплекс у пересечения с улицей Алибегова, студенческий городок и некоторые другие.

В процессе проведения реконструктивных мероприятий, новая застройка далеко не всегда гармонично сочетается со старой. Образуются антиансамбли - группы бессистемной, хаотичной застройки. Каждое здание может иметь выразительный архитектурный облик, но вместе они образуют архитектурный хаос. Серьёзной проблемой является отсутствие соразмерности и сомасштабности размещаемых рядом зданий, например, новая застройка рядом с исторической в Троицком предместье в Минске (рис. 9) и др.

\section{Имеющиеся проблемы и возможности их преодоления}

В белорусских городах сохранилось и работает большое количество промышленных предприятий с устаревшими технологиями очистки выбросов, которые загрязняют городскую среду. Переоснащение промышленности, в том числе создание экологически безвредных производственных предпри-

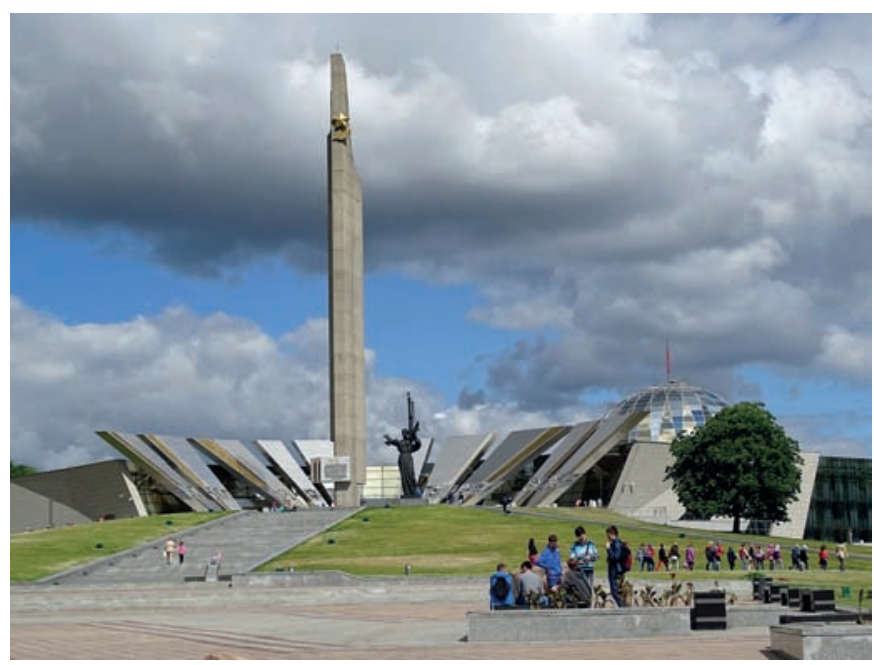

Рис. 5. Белорусский государственный музей Великой Отечественной войны. Минск. Архитектор В. Крамаренко

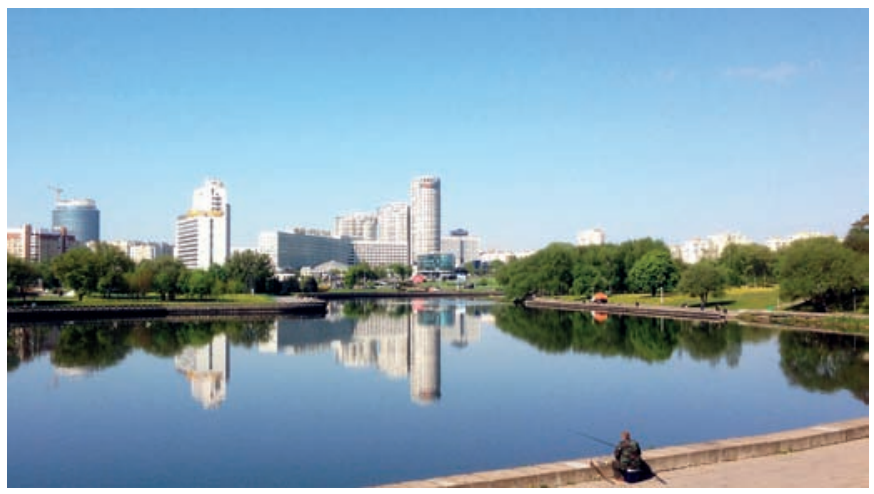

Рис. 6. Искусственная водно-парковая система вдоль реки Свислочь. Минск

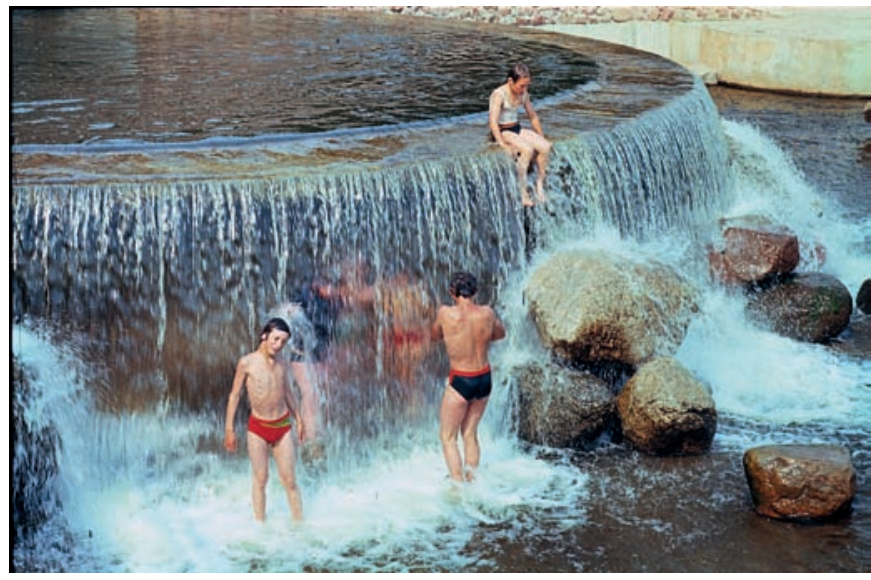

Рис. 7. один из каскадов в составе Слепянской водно-парковой системы. Минск 
ятий, применение безотходных и малоотходных технологий, использование современных технических методов очистки выбросов ведётся медленными темпами.

Крайне высок (в несколько раз выше, чем в странах Европейского (оюза) уровень ресурсопотребления в промышленности и жилищно-коммунальном хозяйстве. Применение альтернативных и возобновляемых источников энергии (энергия солнечного излучения, ветра, малая гидроэнергетика, низкопотенциальное тепло подземных и поверхностных вод, воздуха, тепло производственных и бытовых сточных вод, вентиляционных систем и т.п.) ведется инертно и малоэффективно.

В Беларуси более 70\% жилищного фонда требуют модернизации для снижения энергопотребления. Для решения проблемы энергопотребления ужесточены нормативные требования к теплотехническим характеристикам ограждающих конструкций - стен и окон зданий, что дало хорошие результаты в практике нового строительства, однако застройка прошлых лет реконструируется медленно.

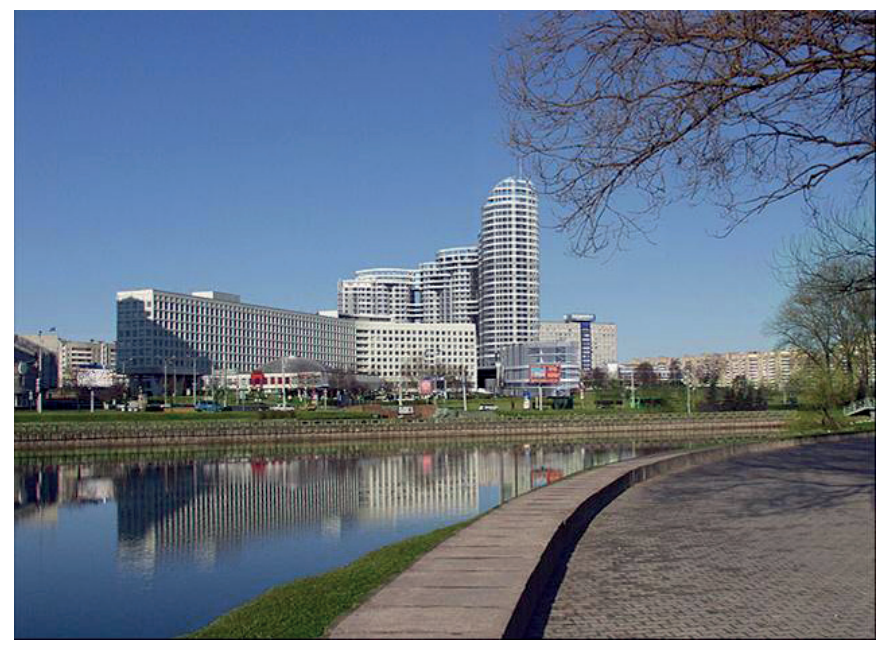

Рис. 8. Архитектурный ансамбль у проспекта Победителей. Минск. Архитектор В. Рондель и др.

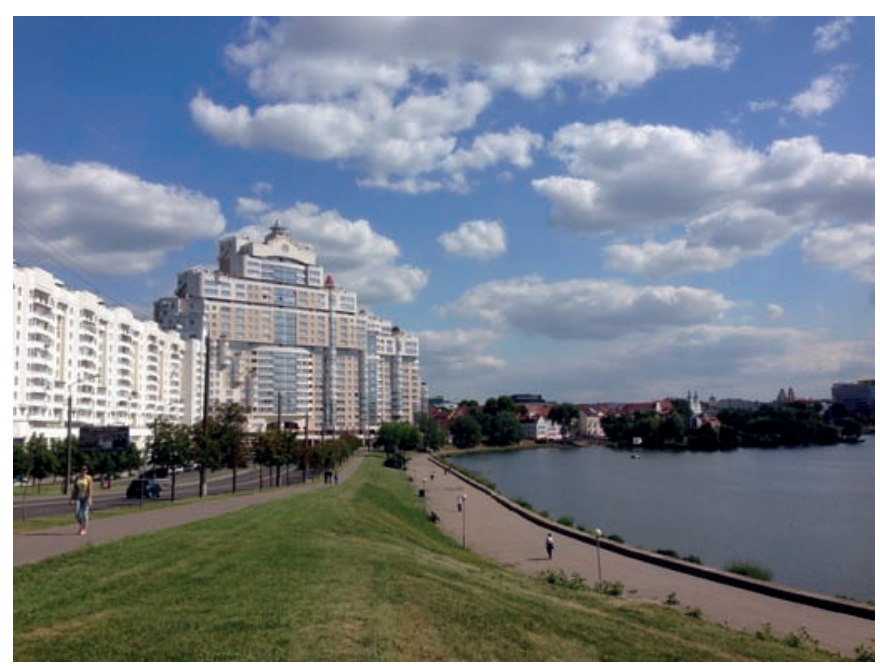

Рис. 9. Пример отсутствия соразмерности и сомасштабности новых зданий, размещённых рядом с историческими в Троицком предместье. Минск
Телекоммуникационные системы и компьютерные технологии управления инженерно-технической и транспортной инфраструктурой применяются пока только в крупных городах Беларуси. Необходимо дальнейшее совершенствование и развитие компьютерных технологий управления инфраструктурой городов; распространение опыта применения компьютерных систем управления на большие и средние города; расширение практики предоставления горожанам удалённого доступа к услугам, развитие городской логистики; использование информационно-коммуникативных технологий в борьбе с терроризмом и преступностью; совершенствование технологий информационной безопасности.

Необходимо сокращение объёма отходов, подлежащих переработке, применение эффективных технологий ликвидации отходов (сжигание мусора на специализированных заводах и теплоэлектростанциях; плазменная газификация бытовых отходов, пиролизная переработка, анаэробная переработка органических отходов и др.).

Важно ввести экономические стимулы применения систем «умный» дом, уменьшения теплопотерь в зданиях за счёт утепления стен и установки современных стеклопакетов, перехода от централизованного отопления к децентрализованному, применения альтернативных источников энергии, раздельного сбора и переработки городских отходов и др.

Системы раздельной канализации (стоки с разным уровнем загрязнения раздельно отводятся к очистным сооружениям) в градостроительной практике не применяются. Не ведётся сбор и рациональное использование дождевой воды.

Реальная обеспеченность жителей городов озеленёнными пространствами неуклонно уменьшается. Чем больше город, тем больше его жители отдаляются от естественной природы: больше горожан, живущих в многоэтажных зданиях, меньше общая озеленённость и площадь озеленённых территорий, приходящаяся на одного человека. Причём показатели обеспеченности населения озеленёнными территориями в городах постоянно уменьшаются как реально, так и в нормах. В условиях, когда в крупных городах высока загрязнённость воздушного бассейна автотранспортом, повышенный уровень шума, необходимо изменить отношение к городским озеленённым территориям и законодательно обеспечить эффективные меры их защиты.

Современный этап развития человеческой цивилизации предусматривает существенное повышение значимости экологических факторов при формировании и развитии городов. «Экологизация» мировоззрения архитекторов и градостроителей согласуется с новой парадигмой общественного развития. Экологически эффективные проекты не создаются случайно, они должны создаваться целенаправленно, путём расширения практики экспериментального проектирования и строительства [6].

\section{Туристский ренессанс исторических городов}

Развитие туризма позволяет активизировать процессы социально-экономического развития городов: увеличить ин- 
вестиции, так как инфраструктура туризма быстро окупается; увеличить поступление средств, в том числе валютных, за счёт обслуживания туристов; увеличить налоговые отчисления в местный бюджет и бюджеты других уровней от объектов туризма и смежных отраслей хозяйственной деятельности; повысить занятость населения за счёт создания новых рабочих мест в системе обслуживания туристов. Развитие туризма создаёт экономическую базу для восстановления, содержания, ремонта историко-культурных ценностей.

В соответствии с Национальной программой развития туризма Республики Беларусь перспективными центрами туризма международного значения определены: Минск, Гродно, Брест, Полоцк, Несвиж, Мир, Новогрудок, Слоним; центрами туризма национального значения - Витебск, Могилев, Гомель, Лида, Орша, Бобруйск, Заславль, Мстиславль, Логойск, Кобрин, Ружаны, Шклов, Поставы, Жировичи, Гольшаны, Волковыск, Будслав.

Особенно важное значение развитие массового туризма имеет для малых городов (рис. 10, 11).

Для развития массового туризма, туристских ресурсов недостаточно, необходима инфраструктура: объекты проживания, питания туристов, развлечений, проведения досуга, объекты информационного обслуживания, туристско-экскурсионного обеспечения, связи и телекоммуникаций, банковских и страховых услуг, торговли, бытового, транспортного обслуживания туристов, спортивно-оздоровительные объекты, объекты оказания медицинской помощи, охраны и поддержания правопорядка.

Организация туризма в городах разных типов имеет особенности (формирование туристских комплексов, зон, трасс, размещение и развитие объектов туристской инфраструктуры, создание туристских маршрутов, оптимизация транспортных и пешеходных связей). Важно сохранение и подчеркивание индивидуального архитектурно-художественного облика городов - центров туризма, обеспечение удобной ориентации туристов в пространстве [7-9].

Города являются результатом деятельности многих поколений творцов. Авторский художественный замысел архитектора-градостроителя, будучи однажды реализованным в натуре, не исчезает бесследно, а включается в предыдущие результаты.

\section{Выводы}

1. Республика Беларусь - урбанизированная страна, в городах проживает 77,5\% населения. За период с 1991 по 2021 год уровень урбанизации увеличился на $11 \%$, ожидается, что в 2030 году он превысит 80\%. При этом наблюдается концентрация населения преимущественно в крупных городах - столице страны и центрах областей, а также в пригородных зонах этих городов.

2. Крупные и большие городах сконцентрированы вдоль транспортно-коммуникационных коридоров международного и национального значения. В качестве экологического противовеса зонам урбанизации ведётся формирование природно-экологического каркаса территории страны, включаю- щего крупные лесные, лесо-озёрные, лесо-речные, болотные природные комплексы, на основе которых создаётся сеть охраняемых природных территорий (национальные природные парки, заповедники, заказники), а также рекреационныхзон.

3. В программных документах в качестве приоритетов градостроительного развития предусмотрено создание гуманных, креативных, «умных», «зелёных» городов. Однако на практике эти постулаты далеко не всегда выполняются. В городах увеличивается этажность и плотность застройки, застраиваются озеленённые территории. Проблемы современных больших городов необходимо решать комплексно - для систем «город-пригород».

4. В архитектурном облике современной городской застройки преобладают «интернациональные» черты. Нивелируется индивидуальность облика городов, городских районов. В городе должны быть символы - узнаваемые, обладающие яркой индивидуальностью архитектурные сооружения, которые ассоциируются с городом, городским районом.

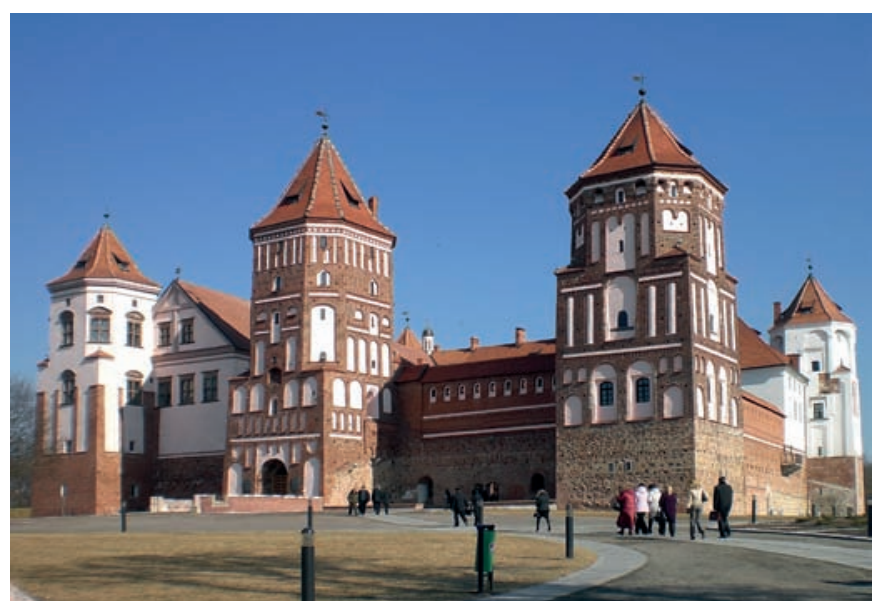

Рис. 10. Мирский замок. Посёлок Мир, Гродненская область, Беларусь. XVI-XVII века. Объект всемирного культурного наследия ЮНЕСКО

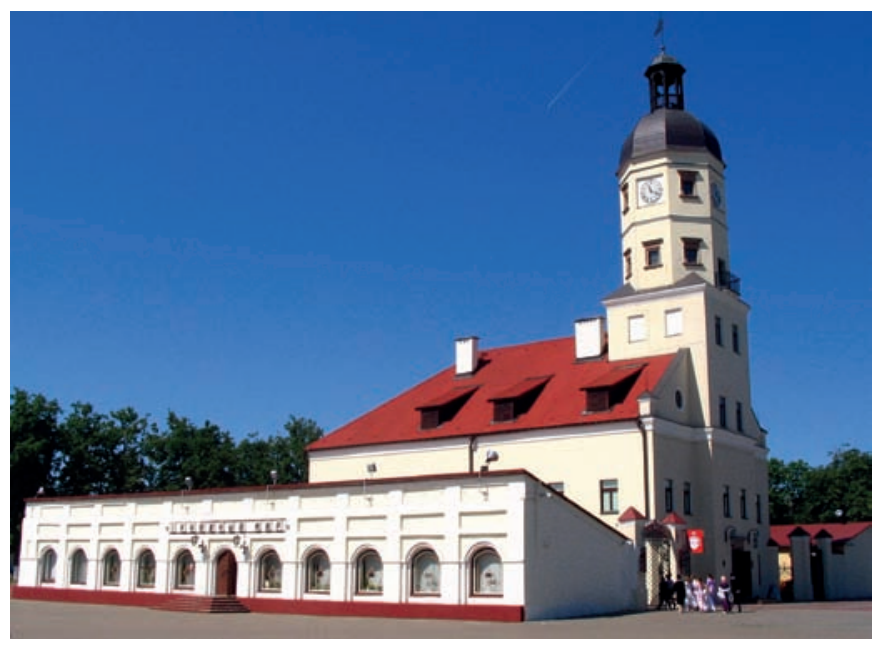

Рис. 11. Историческая ратуша и торговые ряды на центральной площади. Несвиж, Минская область, Беларусь. XVI-XVIII века 


\section{Лumepamypa}

1. Архітэктура Беларусі: нарысы эвалюцыі на усходнеславянскім і еурапейскім кантэксце. Т. 4, кн. 2. Архітэктура XX - пачатку XXI ст. - Мінск: Беларус. Навука, 2009. - 790 c.

2. Потаев, Г.А. Философия современного градостроительства / Г.А. Потаев. - Минск : БНТУ, 2018. - 347 с.

3. Государственная схема комплексной территориальной организации Республика Беларусь. Основные положения. Минск : РУП «БЕЛНИИПградостроительства», 2016. - 40 с.

4. Егоров, Ю.А. Градостроительство Белоруссии / Ю.А. Егоров. - Москва : Стройиздат, 1954. - 282 с.

5. Потаев, Г.А. Экологическая реновация городов / Г.А. Потаев. - Минск : БНТУ, 2009. - 173 с.

6. Белорусская архитектура XX - начала XXI века / А.С. Сардаров, Г.А. Потаев, С.А. Сергачев [и др.]. - Минск : Беларусь, 2020. - $351 \mathrm{c}$.

7. Потаев, Г.А. Планировка, застройка и благоустройство городов - центров туризма / Г.А. Потаев, Г.Р. Потаева. - Минск : «Минсктиппроект», 2011. - 204 С.

8. Боненберг, А. Инструментарий градостроительной композиции / А. Боненберг, Г. Потаев. - Poznan : Wydawnictwo Politechniki Poznanskej, 2018. - 193 c.

9. Потаев, Г.А. Композиция в архитектуре и градостроительстве / Г.А. Потаев. - Москва : ФОРУМ; ИНФРА-М, 2019. -304 c.

\section{References}

1. Arkhitektura Belarusi: narysy evalyutsyi na uskhodneslavyanskim i eurapeiskim kantekstse. T. 4, kn. 2.
Arkhitektura XX - pachatku XXI st. [Architecture of Belarus: essays on evolution in the East Slavic and European context Vol. 4, Book. 2. Architecture of the XX - early XXI century]. Minsk, Belarus, Navuka Publ., 2009, 790 p.

2. Potaev G.A. Filosofiya sovremennogo gradostroitel'stva [Philosophy of modern urban planning]. Minsk, BNTU Publ., 2018, 347 p.

3. Gosudarstvennaya skhema kompleksnoi territorial'noi organi-zatsii Respublika Belarus'. Osnovnye polozheniya [State scheme of complex territorial organization of the Republic of Belarus. Basic provisions]. Minsk, RUP "BELNIIPgradostroitel'stva" Publ., 2016, 40 p.

4. Egorov Yu.A. Gradostroitel'stvo Belorussii [Urban planning of Belarus]. Moscow, Stroiizdat Publ., 1954, 282 p.

5. Potaev G.A. Ekologicheskaya renovatsiya gorodov [Environmental Renovation ofCities]. Minsk, BNTU Publ., 2009,173p.

6. Sardarov A.S., Potaev G.A., Sergachev S.A. [et al.]. Belorusskaya arkhitektura XX - nachala XXI veka [Belarusian architecture of the XX - early XXI century]. Minsk,Belarus' Publ., 2020, 351 p.

7. Potaev G.A. Potaeva. G.R. Planirovka, zastroika i blagoustroistvo gorodov - tsentrov turizma [Planning, development and improvement of cities - tourism centers]. Minsk, “Minsktipproekt" Publ., 2011, 204 p.

8. Bonenberg A., Potaev G. Instrumentarii gradostroitel'noi kompozitsii [Toolkit of urban planning composition]. Poznan, Wydawnictwo Politechniki Poznanskej Publ., 2018, 193 p.

9. Potaev G.A. Kompozitsiya v arkhitekture i gradostroitel'stve [Composition in architecture and urban planning]. Moscow, FORUM, INFRA-M Publ., 2019, 304 p.

Потаев Георгий Александрович (Минск). Доктор архитектуры, профессор. Профессор кафедры «Градостроительство» Белорусского национального технического университета (Республика Беларусь, 220013, г. Минск, пр-т Независимости, 65. БНту). Эл.почта: potaev@tut.by.

Potayev Georgy A. (Minsk). Doctor of Architecture, Professor. Professor at the Department of Urban Development of the Belarusian National Technical University (65 Nezavisimosty Avenue, Minsk, Republic of Belarus, 220013. BNTU). E-mail: potaev@tut.by. 